\title{
The Human $\mu$ Opioid Receptor: Modulation of Functional Desensitization by Calcium/Calmodulin-Dependent Protein Kinase and Protein Kinase C
}

\author{
Anton Mestek, ${ }^{1}$ Joyce H. Hurley, ${ }^{1}$ Leighan S. Bye, ${ }^{1}$ Andrew D. Campbell, ${ }^{1,2}$ Yan Chen, ${ }^{1}$ Mingting Tian, ${ }^{1}$ \\ Jian Liu, ${ }^{1}$ Howard Schulman, ${ }^{3}$ and Lei Yu' \\ 'Department of Medical and Molecular Genetics and 2 Institute of Psychiatric Research, Indiana University School of \\ Medicine, Indianapolis, Indiana 46202 and ${ }^{3}$ Department of Neurobiology, Stanford University School of Medicine, \\ Stanford, California 94305
}

\begin{abstract}
Opioids are some of the most efficacious analgesics used in humans. Prolonged administration of opioids, however, often causes the development of drug tolerance, thus limiting their effectiveness. To explore the molecular basis of those mechanisms that may contribute to opioid tolerance, we have isolated a CDNA for the human $\mu$ opioid receptor, the target of such opioid narcotics as morphine, codeine, methadone, and fentanyl. The receptor encoded by this cDNA is $\mathbf{4 0 0}$ amino acids long with $\mathbf{9 4 \%}$ sequence similarity to the rat $\mu$ opioid receptor. Transient expression of this cDNA in COS-7 cells produced high-affinity binding sites to $\mu$-selective agonists and antagonists. This receptor displays functional coupling to a recently cloned G-proteinactivated $\mathrm{K}^{+}$channel. When both proteins were expressed in Xenopus oocytes, functional desensitization developed upon repeated stimulation of the $\mu$ opioid receptor, as observed by a reduction in $\mathrm{K}^{+}$current induced by the second $\mu$ receptor activation relative to that induced by the first. The extent of desensitization was potentiated by both the multifunctional calcium/calmodulin-dependent protein kinase and protein kinase $\mathrm{C}$. These results demonstrate that kinase modulation is a molecular mechanism by which the desensitization of $\mu$ receptor signaling may be regulated at the cellular level, suggesting that this cellular mechanism may contribute to opioid tolerance in humans.
\end{abstract}

[Key words: opioid receptor, desensitization, G-proteinactivated channel, inward rectifier, protein kinase $C$, calcium/calmodulin-dependent protein kinase, Xenopus oocytes]

Opioid peptides and alkaloids affect a number of physiological functions including hormone secretion, neurotransmitter release, feeding, gastrointestinal motility, and respiratory activity (Pasternak, 1988). Extensive physiological, behavioral, and phar-

\footnotetext{
Received Aug. 15, 1994; revised Oct. 7, 1994; accepted Oct. 13, 1994

We thank Drs. Lily Jan and Henry Lester for their generous gifts of cDNAs encoding the G-protein-activated $\mathrm{K}^{+}$channel, Dr. Leonard Adam for technical advice and Drs. Grant Nicol and Stanley Rane for reviewing the manuscript This work was supported in part by grants from the National Institutes of Health (DA 09116, NS 28190, AA 07611, and GM 30179). L.Y. is a J. Alfred Prufrock investigator and a recipient of an NIH Research Career Development Award (NS 01557).

Correspondence should be addressed to Lei Yu, Ph.D., Department of Medical and Molecular Genetics, Indiana University School of Medicine, 975 West Walnut Street (IBI30), Indianapolis, IN 46202.

Copyright (c) 1995 Society for Neuroscience 0270-6474/95/152396-11\$05.00/0
}

macological studies have defined three major types of opioid receptors designated $\delta, \kappa$, and $\mu$ (Wood and Iyengar, 1988; Corbett et al., 1993). Although there is substantial overlap in their tissue distribution and their pharmacological profiles, each opioid receptor type maintains a unique pattern of expression while displaying characteristic binding affinities for various selective ligands. The $\delta$ receptors that bind the enkephalin peptides are expressed most predominantly in the basal ganglia, striatum, and cerebral cortex (Mansour et al., 1988; Wood, 1988). Although $\delta$ receptors have been implicated in spinal analgesia (Yaksh, 1981; Porreca et al., 1984), recently it has been suggested that specific $\delta$ receptor subtypes may also be involved in supraspinal analgesia (Pasternak, 1993). The $\kappa$ receptors are most highly expressed in cortex, striatum, and hypothalamus (Mansour et al., 1987), with various subtypes identified by autoradiography using selective ligands (Nock et al., 1988; Unterwald et al., 1991). With the development of highly selective ligands, these receptors have been shown to mediate both spinal and supraspinal analgesia (Pasternak, 1993).

The third major class of opioid binding sites is represented by the $\mu$ opioid receptor. It functions as the physiological target of such potent analgesics as morphine and fentanyl, as well as the class of endogenous opioid peptides comprised of $\beta$-endorphin, enkephalins, and dynorphins. The $\mu$ opioid receptor has also been implicated in analgesia (Wood and Iyengar, 1988). Opioid drugs with high abuse liability such as morphine and fentanyl, all bind selectively to the $\mu$ opioid receptor. In addition, heroin (diacetylmorphine), a semisynthetic derivative of morphine, crosses the blood-brain barrier more easily due to its increased hydrophobicity. Once in the brain, heroin is rapidly hydrolyzed to morphine, which acts at the $\mu$ opioid receptor and results in an euphoric effect, thus conferring the reinforcing properties of the drug and contributing to the development of addiction. Because of the high affinity of these opioid narcotics at the $\mu$ receptor, it is considered the main cellular mediator in the development of tolerance (Loh et al., 1988) and opioid addiction (Di Chiara and North, 1992).

The activation of all three opioid receptor types can inhibit adenylyl cyclase and modulate membrane conductances of $\mathrm{Ca}^{2+}$ and $\mathrm{K}^{+}$(Childers, 1993; North, 1993). The increase in $\mathrm{K}^{+}$conductance and the decrease in $\mathrm{Ca}^{2+}$ conductance both serve to reduce membrane excitability and may account for the analgesic properties of the opioids (North, 1993). Electrophysiological recordings from neurons located in the locus coeruleus (Williams 
et al., 1988) and hippocampus (Wimpey and Chavkin, 1991) indicate that $\mu$ opioid receptor stimulation causes membrane hyperpolarization via an inwardly rectifying $\mathrm{K}^{+}$conductance. The effect of the receptors upon the ion channels requires GTP but no diffusible cytosolic molecules. The inhibition of adenylyl cyclase, however, implicates a more complex mode involving opioid regulation of cellular mechanisms, which includes controlling the levels of gene expression as well as modulating the activity of cellular phosphatases and kinases (Di Chiara and North, 1992; Guitart and Nestler, 1993).

Analgesia and the development of opioid tolerance, dependence, and addiction have been the subject of extensive studies (Collin and Cesselin, 1991). Several schemes, including receptor-mediated modulation of membrane conductance, have been proposed for the acute and chronic actions of opioids in the CNS (Johnson and Fleming, 1989). One scheme involves protein phosphorylation by various kinases as a means to regulate opioid-induced cellular processes. The molecular mechanism of such regulation, however, has not been clearly delineated. In the study reported here, we expressed the human $\mu$ opioid receptor and a G-protein-activated $\mathrm{K}^{+}$channel in Xenopus oocytes, and examined the role of protein kinases in modulating the $\mu$ receptor- $\mathrm{K}^{+}$channel coupling and in functional desensitization.

\section{Materials and Methods}

Isolation of the human $\mu$ opioid receptor cDNA. The open reading frame-containing fragment of the rat $\mu$ opioid receptor cDNA was used to screen a $\lambda g t 11$ human cDNA library prepared from caudate nucleus mRNA (Clontech) under conditions of low stringency [6× SSPE $(1.08$ $\mathrm{M} \mathrm{NaCl}, 60 \mathrm{~mm} \mathrm{NaII}{ }_{2} \mathrm{PO}_{4}, 6 \mathrm{~mm}$ EDTA, pH 7.4), $5 \times$ Denhardt's solution $(0.1 \%$ each of Ficoll 400 , polyvinylpyrrolidone, bovine serum albumin), $0.5 \%$ SDS, $100 \mu \mathrm{g} / \mathrm{ml}$ denatured salmon sperm DNA, at $48^{\circ} \mathrm{Cl}$. The final wash was performed in $1 \times$ standard saline citrate $(150$ $\mathrm{mm} \mathrm{NaCl}, 15 \mathrm{~mm}$ sodium citrate) $0.1 \%$ SDS, at $50^{\circ} \mathrm{C}$. Positive $\lambda$ clones were plaque purified and subcloned into pBluescript $\mathrm{KS}(+)$. Sequencing of subclones identified potential opioid-like cDNAs. One was chosen for complete sequence determination of both strands. Potential posttranslational modification sites were identified by using the PCGENE analysis program. Alignment of receptor sequences was performed with the PILEUP program from the Genetics Computer Group software package (Devereux et al., 1984).

RNA blot analysis. A blot from Clontech, containing $2 \mu \mathrm{g}$ of polyadenylated RNA in each lane was used. The RNAs were prepared from various brain regions, dissected, and pooled from normal sources, aged 16 to 75 years old, both male and female, having suffered sudden death but having sustained no injuries to the head. The blot was prehybridized, hybridized, and washed according to the manufacturer's specifications. Briefly, the blot was prehybridized for $6 \mathrm{hr}$ at $42^{\circ} \mathrm{C}$ in a solution containing $5 \times$ SSPE, 10 $\times$ Denhardt's solution, $100 \mu \mathrm{g} / \mathrm{ml}$ denatured, sheared salmon sperm DNA, 50\% formamide, and 2\% SDS. The cDNA probe $(25 \mathrm{ng}$ ) was labeled using random hexamer priming (Pharmacia). Hybridization was performed for $18 \mathrm{hr}$ at $42^{\circ} \mathrm{C}$ with the addition of probe to a density of $2 \times 10^{6} \mathrm{cpm} / \mathrm{ml}$ of prehybridization solution. Final wash conditions were $0.1 \times$ standard saline citrate and $0.1 \%$ SDS at $50^{\circ} \mathrm{C}$ for $40 \mathrm{~min}$. The blot was exposed to Kodak XAR film for autoradiography.

Receptor expression in COS-7 cells. The cDNA containing the open reading frame of the receptor was cloned downstream of the human cytomegalovirus promoter in the mammalian expression vector, pcDNA3 (Invitrogen). COS-7 cells were grown in Dulbecco's modified Eagle's medium (Sigma D-5648) supplemented with $10 \%$ fetal bovine serum and $2 \mathrm{mM} \mathrm{L}$ - glutamine, and were electroporated with supercoiled DNA in $0.4 \mathrm{~cm}$ cuvettes at $250 \mathrm{~V}$, using $3 \times 10^{6}$ cells in a total volume of $0.5 \mathrm{ml}$ containing growth medium, $40 \mu \mathrm{g}$ of expression plasmid, and $200 \mu \mathrm{g}$ of sheared salmon sperm DNA. Cells were harvested $48-72 \mathrm{hr}$ after electroporation. Cells were harvested by scraping into phosphate-

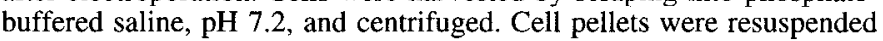
in ice-cold lysis buffer (20 mM Tris- $\mathrm{HCl}$, pH 7.4, $5 \mathrm{~mm}$ EDTA, $1 \mathrm{~mm}$ phenylmethylsulfonyl fluoride) and lysed with a Dounce homogenizer. The homogenate was saved. The pellet was resuspended in lysis buffer and centrifuged as described before. Supernatants were combined and centrifuged for $10 \mathrm{~min}$ at $35,000 \times \mathrm{g}$. Membrane pellets were washed in $50 \mathrm{~mm}$ Tris- $\mathrm{HCl}, \mathrm{pH} \mathrm{7.4}$, centrifuged again, and resuspended in 50 $\mathrm{mm}$ Tris- $\mathrm{HCl}, \mathrm{pH}$ 7.4. Protein concentrations were determined by the method of Bradford (Bradford, 1976).

Binding analysis. Binding assays were performed essentially as described (Chen et al., 1993a). Binding mixtures containing at least 10 $\mu \mathrm{g}$ membrane protein were incubated at room temperature for $90 \mathrm{~min}$ in $50 \mathrm{mM}$ Tris- $\mathrm{HCl}, \mathrm{pH} 7.4$ containing $0.2 \%$ bovine serum albumin, various concentrations of unlabeled ligands, and ${ }^{3} \mathrm{H}$-diprenorphine $\left({ }^{3} \mathrm{H}-\right.$ DPN) or ${ }^{3} \mathrm{H}-\left[\mathrm{D}-\mathrm{Ala}^{2}, \mathrm{~N}-\mathrm{MePhe}^{4}, \mathrm{Gly}-\mathrm{ol}^{5}\right]$-enkephalin ( $\left.{ }^{3} \mathrm{H}-\mathrm{DAMGO}\right)$, in a final volume of $200 \mu \mathrm{l}$. Reactions were terminated by quickly adding $3 \mathrm{ml}$ of ice-cold binding buffer ( $50 \mathrm{~mm}$ Tris- $\mathrm{HCl}, \mathrm{pH} 7.4$ ) followed by vacuum filtration onto Whatman GF/B glass fiber filters, presoaked for $3 \mathrm{hr}$ in $0.2 \%$ polyethylenimine to minimize nonspecific binding. Filters were washed two times each with $3 \mathrm{ml}$ of ice-cold binding buffer before placed in vials containing $10 \mathrm{ml}$ liquid scintillation cocktail (CytoScint) Radioactivity was determined using a Beckman LS-5801 scintillation counter. Nonspecific binding was defined as the radioactivity bound in the presence of $10 \mu \mathrm{M}$ unlabeled naloxone. Saturation analyses were performed as above with increasing concentrations of ${ }^{3} \mathrm{H}-\mathrm{DPN}(0.01$ to $2.5 \mathrm{nM})$ or ${ }^{3} \mathrm{H}-\mathrm{DAMGO}(0.05$ to $5 \mathrm{nM})$.

Data for all saturation binding experiments were analyzed by using the linear/nonlinear regression analysis program EBDA/LIGAND (Munson, 1983) to obtain estimates of equilibrium dissociation constant $\left(K_{d}\right)$, Hill slope $\left(n_{\mathrm{H}}\right)$, and binding site density $\left(B_{\max }\right)$ values. Competition curves were obtained with $1.3 \mathrm{nM}{ }^{3} \mathrm{H}$-DAMGO incubated with concentrations of the indicated competitors from $0.01 \mathrm{nM}$ to $5 \mu \mathrm{M}$. $\mathrm{IC}_{50}$ values were determined through nonlinear regression using InPlot, which utilizes the Cheng-Prusoff equation to determine the $K_{i}$ values (Cheng and Prusoff, 1973).

Oocyte expression of the receptor and the G-protein-activated $\mathrm{K}^{+}$ channel. The cloning of the G-protein-activated inwardly rectifying $\mathrm{K}^{+}$ channel has been described (Dascal et al., 1993; Kubo et al., 1993). Synthetic mRNAs for the human $\mu$ opioid receptor and the G-proteinactivated $\mathrm{K}^{+}$channel were transcribed in vitro, as described (Chen and $\mathrm{Yu}, 1994)$. RNA yield was calculated from incorporation of the radioactive precursor, $\alpha^{3}{ }^{32} \mathrm{P}-\mathrm{UTP}$.

Oocytes were isolated using standard methods (Gurdon and Wickens, 1983). Ovarian lobes were surgically removed from mature Xenopus laevis females, and individual oocytes were isolated by digestion with $2 \mathrm{mg} / \mathrm{ml}$ collagenase in OR-2 [82.5 mM NaCl, $2 \mathrm{mM} \mathrm{KCl}, 1 \mathrm{~mm} \mathrm{MgCl}$, $5 \mathrm{~mm} N$-[2-hydroxyethyl]piperazine- $N^{\prime}$-[2-ethanesulfonic acid] (HEPES), $\mathrm{pH} 7.5$ ] for $\mathrm{l}-2 \mathrm{hr}$ at room temperature. Stage $\mathrm{V}$ and VI oocytes were injected with a total of $50 \mathrm{nl}$ containing $0.1 \mathrm{ng}$ of each mRNA and incubated for $2-3 \mathrm{~d}$ at $20^{\circ} \mathrm{C}$ in ND96 $(96 \mathrm{~mm} \mathrm{NaCl}, 2 \mathrm{mM}$ $\mathrm{KCl}, 1 \mathrm{mM} \mathrm{MgCl}$ and $1.5 \mathrm{mM} \mathrm{CaCl}_{2}$ ) supplemented with $10 \mu \mathrm{g} / \mathrm{ml}$ gentamycin and $5 \%$ fetal bovine serum.

Flectrophysiology. Oocytes were voltage clamped using a two-microelectrode voltage clamp, and the data were analyzed with pCLAMP software (Axon Instruments). The electrodes were filled with $3 \mathrm{M} \mathrm{KCl}$ and had tip resistances of $0.5-10 \mathrm{M} \Omega$ Oocytes were superfused with either a high $\mathrm{K}^{+}$solution, $\mathrm{HK}\left(96 \mathrm{mM} \mathrm{KCl}, 2 \mathrm{~mm} \mathrm{NaCl}, 1 \mathrm{~mm} \mathrm{MgCl}_{2}\right.$, and $1.5 \mathrm{mM} \mathrm{CaCl}_{2}$ ) or ND96 containing the appropriate agonist or kinase modulator. Phorbol 12-myristate 13-acetate (PMA), a protein kinase C (PKC) activator, and $4 \alpha$-phorbol, an inactive phorbol ester, were diluted to final concentrations of $100 \mathrm{nM}$ in ND96 for oocyte superfusion. Type II multifunctional calcium/calmodulin-dependent protein kinase (CaM kinase II) was purified from rat brain as described (Schulman, 1984). The holoenzyme was activated to become $\mathrm{Ca}^{2+} /$ calmodulin-independent by autophosphorylation as described (Waldmann et al., 1990) with the following modifications: CaM kinase II $(75 \mathrm{nM})$ was incubated with $1 \mu \mathrm{M}$ calmodulin, $100 \mu \mathrm{M}$ adenosine $5^{\prime}$. $O$-thiotriphosphate (ATP- $\gamma \mathrm{S}$ ), $0.1 \mathrm{mM} \mathrm{CaCl}_{2}, 2 \mathrm{~mm}$ dithiothreitol (DTT), $40 \mathrm{~mm}$ HEPES, pH 7.4 at $4^{\circ} \mathrm{C}$ for $20 \mathrm{~min}$. EGTA was added to a final concentration of $0.12 \mathrm{~mm}$. Aliquots of autophosphorylated CaM kinase II were stored at $-70^{\circ} \mathrm{C}$ until used. Oocytes were injected with $50 \mathrm{nl}$ of the reaction mixture ( $2 \mathrm{fmol}$ of $\mathrm{CaM}$ kinase II per cell). Desensitization was defined as a decrease in the response of the oocyte to a second application of agonist and was quantitatively determined for each oocyte as the ratio of the $\mathrm{K}^{+}$current induced by the second stimulation relative to that induced by the first. In all current traces, the initial inward current is due to switching the superfusate from ND96 (2 $\mathrm{mM} \mathrm{KCl}$ ) to $\mathrm{HK}$ ( $96 \mathrm{mM} \mathrm{KCl)}$. Analysis of variance and Student's $t$ test were used to compare the treatment groups. 


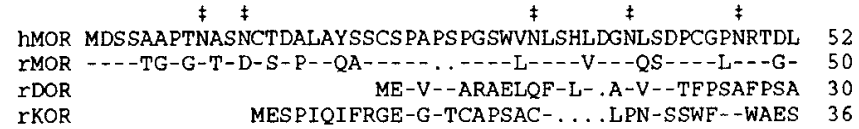

hMOR GGRDSLCPP. . . TGSP. SMITAIT IMALYSIVCVVGLFGNFLVMYVIVRYT 99

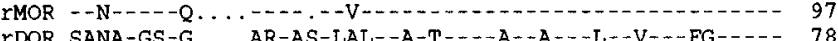
rKOR DSNG-VGSEDQQLEPAHI-PAIPVI-T-V--V-F--- - V- $-5---F--I---88$ TMI

8 = hMOR KMKTATNIYIFNLALADALATSTLPFOSVNYLMGTWPFGTILCKIVISIDYY 151 YMOR _. _ _ _. IDOR -LIKOR - $1 .-140$

hMOR NMFTSIFTLCTMSVDRYIAVCHPVKALDFRT PRNAKI INVCNWILGSAIGLP 203 YMOR rDOR rKOR =-..-TM-....... TM3 TM4

IMOR VMFMATTKYRQ . GSIDCTLTFSHPTW. YWENLLKICVFIFAF IMPVLIITV 252 IMOR - - IDOR I-V--V-QP-D. . -AVV---Q-PS-S-. --DTVT-----L---VV-I----- 231 rKOR AIVLGG--V-EDVDV-E-S-Q-PDDEYSW-DLFM-_---V---VI …ㄹ 244

$\stackrel{\text { Z }}{\text { hMOR CYGLMILRLKSVRMLSGSKEKDRNLRRITRMVLVVVAVF IVCWTPIHIYVII } 304}$

$\stackrel{\text { Z }}{\text { hMOR CYGLMILRLKSVRMLSGSKEKDRNLRRITRMVLVVVAVF IVCWTPIHIYVII } 304}$ YMOR -

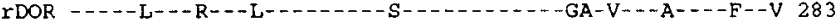

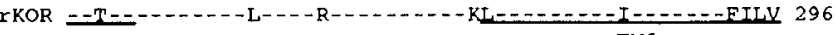
TM6

$\downarrow$

hMOR KALVTI. PETTFQTVSWHFCIALGYTNSCLNPVLYAFLDENFKRCFREFCIP 355 YMOR - - - . . . - .

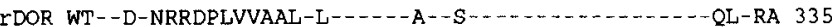

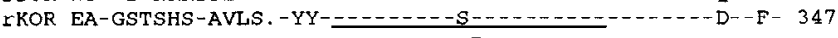
TM7

$\nabla$ hMOR TSSNIEOONSTRIRONTRDHPSTANTVDRTNHOLENLEAETAPLP YMOR - - T- IDOR PCGGQ-PGSLR-P--A-ARERV--C-PS . . . . DGPGGGA-A IKOR IKMRM-R-STN-V-.-VOD-ASMRD-GGM-KPV

Figure 1. Sequence comparison of the human and rat opioid receptors and expression of the human $\mu$ opioid receptor in human brain. Seven putative transmembrane domains are underlined and numbered TMI through TM7. Amino acids identical to those in the human $\mu$ opioid receptor are depicted as hyphens (-). Gaps are shown by periods (.). Putative N-linked glycosylation sites $(\ddagger)$; potential site for phosphorylation by multifunctional $\mathrm{Ca}^{2+} /$ calmodulin-dependent protein kinase (CaM kinase II) ( $)$; conserved aspartic acid residues proposed to interact with the amine group of ligands $(\$)$; conserved cysteine residues that may form a disulfide bond $(=)$; potential sites for phosphorylation by protein kinase $\mathrm{C}(\mathrm{PKC})(\nabla)$; putative phosphorylation site for PKC or CaM kinase II $(\nabla)$; potential phosphorylation site for CaM kinase II or cAMP-dependent kinase A $(\uparrow)$; potential palmitoylation site $(\downarrow)$. The cDNA sequence has been submitted to GenBank (accession number L29301).

\section{Results}

Isolation and characterization of $c D N A$ encoding the human $\mu$ opioid receptor

To clone the human $\mu$ opioid receptor, a cDNA library constructed from human caudate nucleus mRNA was screened under reduced stringency with the rat $\mu$ opioid receptor cDNA (Chen et al., 1993a), and the cDNA inserts from positive clones wcrc subcloned into pBluescript. Complete sequence analysis of one cDNA revealed an open reading frame of 1200 base pairs (bp), predicting a protein of 400 amino acids. Hydropathy analysis of the deduced protein indicated the presence of seven hy- drophobic domains, typical of G-protein-coupled receptors (Collins et al., 1991). The sequence of this protein displays $94 \%$ similarity to the rat $\mu$ opioid receptor (Chen et al., 1993a; Wang et al., 1993; Fukuda et al., 1993; Thompson et al., 1993), suggesting that it is the human homolog of the $\mu$ opioid receptor. It also displays $62 \%$ and $58 \%$ similarities to the murine $\delta$ (Kieffer et al., 1993; Evans et al., 1993; Fukuda et al., 1993) and $\kappa$ (Chen et al., 1993b; Li et al., 1993; Meng et al., 1993; Minami et al., 1993; Yasuda et al., 1993) opioid receptors, respectively. Figure 1 displays the alignment of the human $\mu$ opioid receptor sequence against the rat $\mu, \kappa$, and $\delta$ opioid receptor sequences.

The regions of greatest divergence among the different types of opioid receptors include the $\mathrm{N}$ - and C-termini, the fourth and sixth transmembrane domains, and the second and third extracellular loops. Several potential sites for posttranslational modification are present (Fig. 1). The N-terminus contains five potential N-linked glycosylation sites that remain conserved between the human and rat $\mu$ opioid receptors. Aspartic acid residues that occur in other G-protein-coupled receptors and have been shown to interact with the protonated amine group of various ligands (Dohlmann et al., 1991) are also present in the putative transmembrane domains TM2 and TM3 of the $\mu$ receptor, and two conserved cysteine residues believed to be involved in disulfide bonding (Dixon et al., 1988) occur in the first and second extracellular loops. There are also potential phosphorylation sites for CAMP-dependent protein kinase (PKA) and PKC, as well as $\mathrm{CaM}$ kinase. One of these sites, conserved among all opioid receptor types, occurs in the third intracellular loop. This region between TM5 and TM6 is often referred to as the G-protein loop because of its importance in G-protein coupling (Dohlmann et al., 1991). The conscrvation of this site suggests that phosphorylation may play a role in modulating signal transduction of all the opioid receptors. There is also a cysteine residue in the $\mathrm{C}$-terminus that is conserved among many $\mathrm{G}$-proteincoupled receptors and that may serve as a target for palmitoylation (Collins et al., 1991).

\section{Expression of the receptor $m R N A$ in human brain}

To estimate the relative abundance of the $\mu$ opioid receptor mRNA, a blot containing polyadenylated RNA from various regions of the human brain was hybridized with a probe containing the open reading frame of the human $\mu$ opioid receptor cDNA (Fig. 2). The predominant mRNA is approximately 14 kilobases (kb), similar in size to those reported for the rat $\mu$ opioid receptor (Fukuda et al., 1993; Thompson et al., 1993; Delfs ct al., 1994). This message is abundant in the thalamus, hypothalamus, and subthalamic nucleus where $\mu$ opioid receptors are helieved to modulate nociception. Somewhat lower levels of message are observed in the caudate nucleus and amygdala, which harbor synapses between cortical neurons and motor nuclei located in the brainstem and spinal cord. These basal ganglia as well as the subthalamic nucleus that serves as a "way station" for this extrapyramidal tract may allow for opioid-mediated integration of somatosensory input and motor output. The substantia nigra, corpus callosum, and hippocampus express the $\mu$ receptor mRNA in lower abundance than that seen in the other brain subregions. Recent in situ hybridization studies in rat brain (Thompson et al., 1993; Delfs et al., 1994) have provided cellular resolution of $\mu$ opioid receptor message expression and corroborate our results of the subregion RNA analysis. 


\section{Pharmacological characterization of the receptor}

The cDNA containing the open reading frame was subcloned into a mammalian expression vector containing the human cytomegalovirus promoter. This construct was transiently expressed in COS-7 cells, and saturation binding of ${ }^{3} \mathrm{H}$-diprenorphine to the membranes was performed. As shown in Figure $3 A$, a saturable binding was observed with a $K_{d}$ of $0.23 \pm 0.01 \mathrm{nM}$ $(n=3)$ and a $B_{\max }$ of $549 \pm 26 \mathrm{fmol} / \mathrm{mg}$ of membrane protein. Hill coefficients $(0.97 \pm 0.01)$ did not suggest the presence of any cooperative binding effects. The equilibrium binding parameters for ${ }^{3} \mathrm{H}$-DAMGO, a $\mu$-selective agonist, were $1.6 \pm 0.15$ $\mathrm{nM}$ for the $K_{d}$ and $381 \pm 25 \mathrm{fmol} / \mathrm{mg}$ membrane protein for $B_{\max }$.

To characterize the pharmacological profile of this receptor, competitive displacement experiments were performed with various opioid ligands. Representative binding isotherms are shown in Figure $3 B$, and $\mathrm{IC}_{50}$ and $K_{i}$ values are summarized in Table 1. The $\mu$-selective agonist, DAMGO, displaced ${ }^{3} \mathrm{H}$-DAMGO binding with high affinity $\left(K_{i}=0.9 \mathrm{nM}\right)$. Two other opioid ligands, [D-Pen ${ }^{2.5}$ ]enkephalin (DPDPE) and U-50,488, which are selective for $\delta$ and $\kappa$ receptors, respectively, displayed low-affinity binding with $K_{i}$ values above the $\mu \mathrm{M}$ range. Displacement of ${ }^{3} \mathrm{H}$-DAMGO from membranes expressing the human $\mu$ opioid receptor was also performed using opioid antagonists. Cyprodime and naloxonazine, both $\mu$-selective antagonists, bound with $K_{i}$ values in the nM range. Naloxone, a nonselective opioid antagonist, bound with an affinity nearly equal to that of DAMGO. The rank order affinity for these ligands (Table 1) and the high affinity for $\mu$-selective ligands indicate that this cDNA encodes a $\mu$ opioid receptor.

Competitive displacement binding was also done with several therapeutic opioid ligands. Morphine, methadone, and fentanyl, archetypal drugs that bind the $\mu$ opioid receptor, all displayed nM affinity. Codeine showed lower affinity with $K_{i}$ values in the high nm range. Several endogenous opioid peptides were also tested. Met-enkephalin, Leu-enkephalin, and $\beta$-endorphin all displayed high affinities comparable to that observed for DAMGO, suggesting that they may act at this receptor in vivo.

\section{Functional coupling to a G-protein-activated $K^{+}$channel}

Activation of opioid receptors has been known to affect membrane permeability to potassium (North, 1993). Stimulation of the $\mu$ opioid receptor hyperpolarizes cellular membranes by increasing the $\mathrm{K}^{+}$conductance through an inwardly rectifying channel (North et al., 1987; Wimpey and Chavkin, 1991). The recent cloning of an inwardly rectifying $\mathrm{K}^{+}$channel (Dascal et al., 1993; Kubo et al., 1993) had shown that it is expressed in the brain. We were interested in testing whether the human $\mu$ opioid receptor coupled to this $\mathrm{G}$-protein-activated $\mathrm{K}^{+}$channel. Messenger RNAs encoding both proteins were generated by in vitro transcription and injected into Xenopus oocytes. Coupling of the receptor to the $\mathrm{K}^{+}$channel was assessed by two-electrode voltage clamp. When the receptor was activated by superfusing the oocytes with DAMGO, an inward current was observed (Fig. $4 A$ ). This was a $\mathrm{K}^{+}$current through the inwardly rectifying $\mathrm{K}^{+}$ channel, since the current varied in amplitude with the concentration of $\mathrm{K}^{+}$in the extracellular solution and was blocked by the $\mathrm{K}^{+}$channel blocker $\mathrm{Ba}^{2+}(100 \mu \mathrm{M})$. Oocytes injected with the receptor mRNA alone did not produce the current upon DAMGO stimulation (data not shown). This $\mathrm{K}^{+}$current was induced by activation of the $\mu$ opioid receptor, since the current

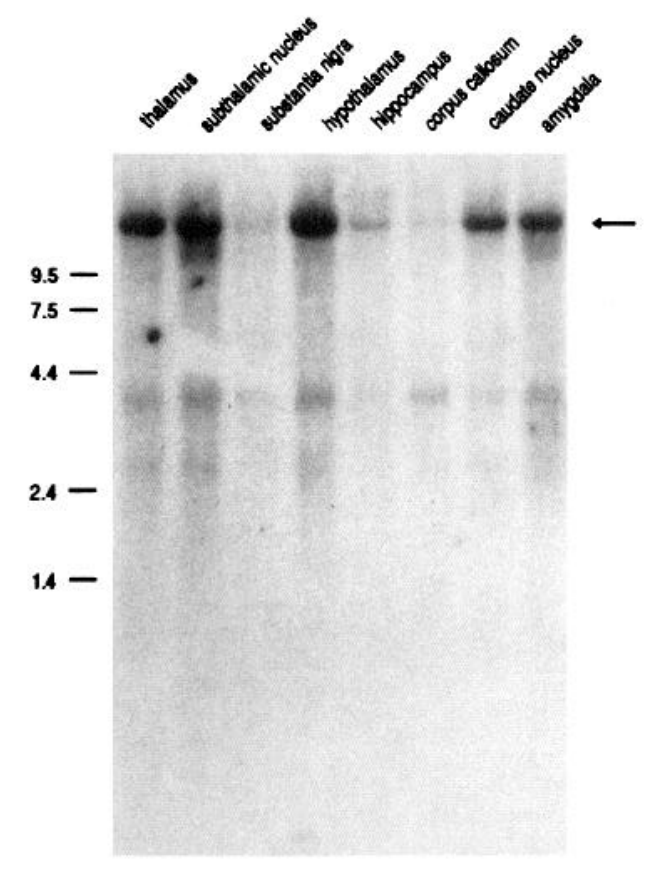

Figure 2. RNA blot analysis of the $\mu$ opioid receptor message in various regions of the human brain. The size markers are indicated on the left. The predominant $14 \mathrm{~kb}$ band is marked by an arrow.

produced by exposure to DAMGO was completely blocked by the opioid antagonist naloxone (Fig. $4 B$ ). The current-voltage relationship of this $\mathrm{K}^{+}$channel was characteristic of an inward rectifier. With progressive hyperpolarization, the magnitude of current increased (Fig. 4C). However, as the membrane was depolarized, current flow decreased until there was little to none at a membrane potential of $0 \mathrm{mV}$. Thus, the human $\mu$ opioid receptor is capable of coupling to the G-protein-activated $\mathrm{K}^{+}$ channel.

\section{Repeated agonist stimulation desensitizes receptor-channel coupling}

Prolonged exposure to opioids are known to produce tolerance (Di Chiara and North, 1992). At the cellular level, tolerance is manifested as a diminished response to opioids (Johnson and Fleming, 1989). Since the opioid narcotics with abuse liability, such as morphine and fentanyl, display high affinity at the $\mu$ opioid receptor (Table 1), we were interested in examining whether the intracellular signaling by the $\mu$ opioid receptor displays desensitization. Using the receptor- $\mathrm{K}^{+}$channel coupling as an assay, oocytes were subjected to repeated agonist stimulation to determine whether functional desensitization of the $\mu$ receptor- $\mathrm{K}^{+}$channel coupling occurs. For this purpose, a protocol of repeated agonist application was used (Fig. 5A, top), and "desensitization" was operationally defined as a reduction in the responsiveness of the cell. Due to the variation in mRNA expression among different cells, the amplitude of the $\mathrm{K}^{+}$currents vary from oocyte to oocyte. Therefore, desensitization was quantitatively described as a ratio of two DAMGO-induced $\mathrm{K}^{+}$ currents in the same oocyte. Current traces at $-80 \mathrm{mV}$ were recorded for each stimulation with DAMGO to evaluate the extent of desensitization. In addition, currents over the entire voltage range between $-160 \mathrm{mV}$ and $+40 \mathrm{mV}$ were recorded using either ramped (Fig. $5 A$, middle) or stepped voltage commands (Fig. $5 A$, bottom). Repeated stimulation of the $\mu$ receptor re- 
Figure 3. Saturation and displacement binding of labeled ligands using cell membranes transiently expressing the human $\mu$ opioid receptor. $A$, Saturation binding of ${ }^{3} \mathrm{H}$-diprenorphine (DPN) was determined using membranes prepared from cDNA-transfected COS-7 cells. Data for all saturation binding experiments were analyzed using the linear/nonlinear regression analysis program EBDA/LIGAND (Munson, 1983) to obtain estimates of $K_{d}$ and $B_{\max }$ values. Data represent mean \pm standard error mean (SEM) of three separate experiments performed in duplicate. Inset: Saturation binding plotted in Scatchard coordinates (representative curve shown). $B$, Displacement of ${ }^{3} \mathrm{H}$-DAMGO binding with unlabeled ligands as competitors. Displacement of ${ }^{3} \mathrm{H}$-DAMGO binding was performed using $1.3 \mathrm{nM}{ }^{3} \mathrm{H}$-DAMGO and unlabeled competitors with concentrations ranging from $0.01 \mathrm{nM}$ to $5 \mu \mathrm{M}$. Data represent mean \pm SEM of three separate experiments performed in duplicate.
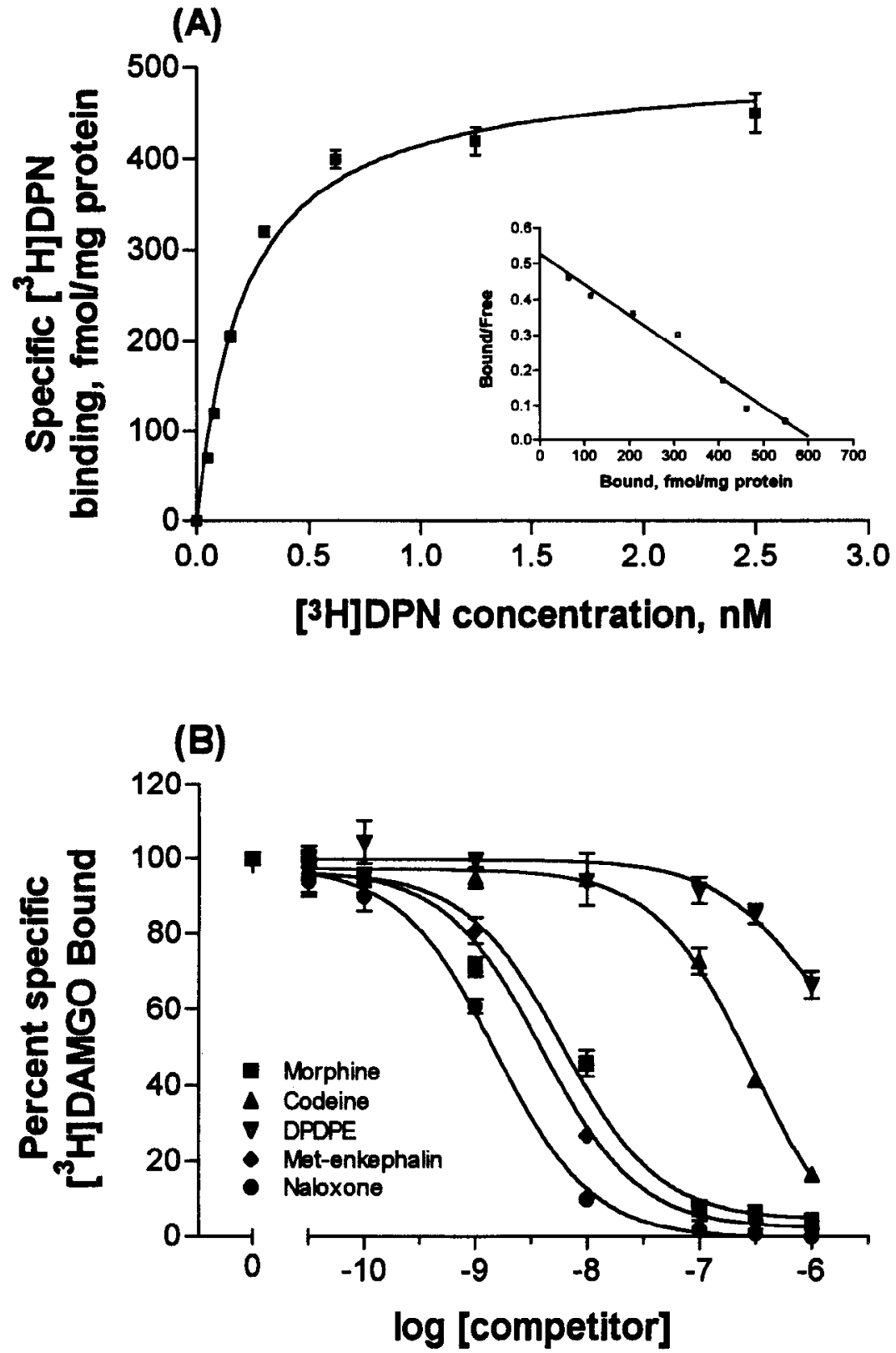

sulted in a moderate and consistent desensitization, as observed by a reduction in the second response. The second response was reduced to $83 \% \pm 8 \%(n=4)$ relative to the first (Fig. 7), and subsequent stimulation of the oocyte with DAMGO did not result in any further decrease in the inward current (data not shown).

\section{Protein kinases potentiate desensitization of receptor-channel coupling}

Previous studies had shown that activation of PKC was capable of attenuating opioid receptor activity in neuroblastoma cells (Louie et al., 1990) as well as affecting ionic conductances using acutely dissociated neurons in culture (Doerner et al., 1988). We were interested in observing whether stimulation of PKC affects the coupling of the human $\mu$ opioid receptor to the $\mathrm{K}^{+}$channel. Using the protocol described above (Fig. 5A, top), Xenopus oocytes were superfused for 10-15 min after the initial DAMGO stimulation with PMA, a PKC-activating phorbol ester. Oocytes were again stimulated with DAMGO. Comparison between the peak current responses to DAMGO before and after PMA treatment reveals the extent of desensitization (Fig. 5B, top). PMA reduced the second response to $29 \% \pm 7 \%(n=4)$ relative to the first (Fig. 7) at the holding potential of $-80 \mathrm{mV}$. Current responses were also obtained using a ramped voltage command. Representative current traces from before and after PMA treatment are superimposed (Fig. $5 B$, middle). Currents produced by stepped voltage commands were measured and the reduction in response was shown to be proportionally uniform across the voltage range (Fig. 5B, bottom). Thus, activation of PKC potentiated the desensitization of the $\mu$ opioid receptor-activated $\mathrm{K}^{+}$ current. To control for possible nonspecific effects caused by application of a phorbol ester to the cellular membrane, oocytes were treated with $4 \alpha$-phorbol, a phorbol ester that does not activate PKC (Blumberg et al., 1984). Recordings of peak current amplitude showed that the $4 \alpha$-phorbol did not potentiate desensitization $(87 \% \pm 2 \%, n=4)$ beyond that observed with no 
Table 1. $\mathrm{IC}_{50}$ and $K_{i}$ values of various opioid receptor ligands for the cloned human $\mu$ receptor

\begin{tabular}{lcc} 
Competitor & $\mathrm{IC}_{50}(\mathrm{nM})$ & \multicolumn{1}{c}{$K_{i}(\mathrm{nM})$} \\
\hline$\beta$-Endorphin & $3.4 \pm 0.5$ & $1.8 \pm 0.3$ \\
Leu-enkephalin & $17.7 \pm 7.4$ & $9.5 \pm 4.0$ \\
Met-enkephalin & $4.1 \pm 0.1$ & $2.2 \pm 0.1$ \\
DAMGO & $1.7 \pm 0.4$ & $0.9 \pm 0.2$ \\
DPDPE & $>1000$ & $>1000$ \\
U-50, 488 & $>1000$ & $>1000$ \\
Morphine & $6.6 \pm 0.5$ & $3.6 \pm 0.3$ \\
Fentanyl & $4.8 \pm 0.8$ & $2.6 \pm 0.4$ \\
Methadone & $6.9 \pm 0.1$ & $3.7 \pm 0.03$ \\
Codeine & $235.3 \pm 14.5$ & $128.0 \pm 8.7$ \\
Naloxone & $1.5 \pm 0.2$ & $0.8 \pm 0.1$ \\
Naloxonazine & $1.8 \pm .2$ & $1.0 \pm 0.1$ \\
CHB & $25.6 \pm 9.5$ & $14.1 \pm 5.3$
\end{tabular}

Competition curves were obtained with $1.3 \mathrm{nM}{ }^{3} \mathrm{H}$-DAMGO incubated with concentrations of the indicated competitors ranging from $0.01 \mathrm{nM}$ to $5 \mu \mathrm{M}(200$ $\mu l$ final volume). $\mathrm{IC}_{50}$ values were determined using nonlinear regression. $K_{i}$ values were calculated using the Cheng-Prusoff equation (Cheng and Prusoff, 1973). Values shown are mean \pm SEM of three experiments performed in duplicate. CHB, cyprodime HBr; DAMGO, [n-Ala ${ }^{2}, \mathrm{~N}-\mathrm{MePhe}^{4}, \mathrm{Clly}^{\left.-0 l^{5}\right]-e n-}$ kephalin; DPDPE, [D-Pen ${ }^{2.5}$ ]enkephalin.

treatment (Figs. $5 C$, top; 7). Membrane currents from ramped (Fig. $5 C$, middle) and stepped voltage commands (Fig. $5 C$, bottom) before and after $4 \alpha$-phorbol treatment exhibited moderate desensitization comparable to that with no treatment (data not shown), demonstrating that the inactive form of the phorbol ester did not potentiate desensitization. Therefore, these results indicate that potentiation of the desensitization by PMA reffects the activation of PKC.

Physiologically, PKC is activated by diacylglycerol (DAG), a second messenger of the phosphatidylinositol pathway. This signaling pathway also generates another second messenger, inositol 1,4,5-trisphosphate $\left(\mathrm{IP}_{3}\right)$, which triggers an increase in intracellular calcium and results in the activation of CaM kinase II (Schulman and Hanson, 1993). We were interested in testing whether CaM kinase II could modulate the $\mu$ opioid receptormediated $\mathrm{K}^{+}$current. Using the protocol described above, oocytes were injected with the activated form of CaM kinase II between the first and second stimulations by DAMGO, and the effect on the receptor-induced $\mathrm{K}^{+}$current was evaluated. Injection of activated CaM kinase II reduced the second response to $44 \% \pm 4 \%(n=8)$ compared to the first (Figs. 6A, top; 7$)$. CaM kinase II clearly potentiated the desensitization, causing a twofold decrease in the second response relative to uninjected oocytes. This reduction in the second response was proportional across the entire voltage range (Fig. $6 A$, middle and bottom). As a negative control, the same CaM kinase II solution was placed in a boiling water bath for $5 \mathrm{~min}$ and chilled on ice before injection into the oocytes. Boiled CaM kinase II did not potentiate desensitization ( $84 \% \pm 8 \%, n=8$ ) beyond that observed with uninjected controls (Figs. $6 B$, top; 7). Currents measured during the ramped or stepped voltage commands were similar both before and after injection of boiled CaM kinase II (Fig. $6 B$, middle and bottom). We concluded that activated CaM kinase II can therefore potentiate the desensitization of the $\mu$ opioid receptor-activated $\mathrm{K}^{+}$current.
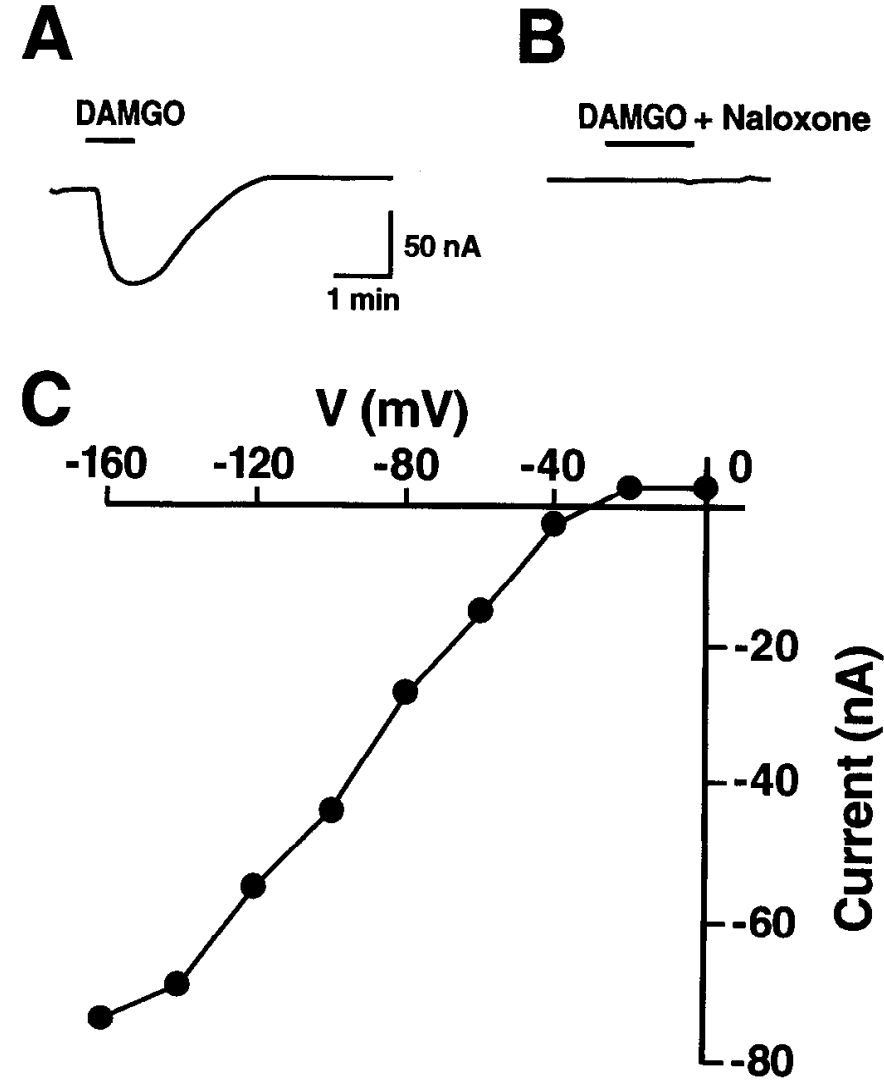

Figure 4. Human $\mu$ opioid receptor coupling to the G-protein-activated $\mathrm{K}^{+}$channel. Electrophysiological analysis of oocytes injected with RNAs encoding the human $\mu$ opioid receptor and the G-protein-activated $\mathrm{K}^{+}$channel. Membrane current traces were recorded at a holding potential of $-80 \mathrm{mV}$. Oocytes were bathed in a high $\mathrm{K}^{+}$solution and were exposed to either $(A) 1 \mu \mathrm{M}$ DAMGO or $(B) 1 \mu \mathrm{M}$ DAMGO plus $10 \mu \mathrm{M}$ naloxone. Inward current is downward. $C$, The current-voltage relationship plotted as an $I / V$ curve. DAMGO-induced membrane currents were recorded with voltage steps ranging from $160 \mathrm{mV}$ to 0 $\mathrm{mV}$. The DAMGO-induced net currents were derived by subtracting the currents recorded before DAMGO application from those during DAMGO application.

\section{Discussion}

The $\mu$ opioid receptor mediates the effects of such potent analgesics as morphine, codeine, and fentanyl. To explore the molecular basis of opioid actions and the possible mechanisms involved in tolerance development, a cDNA clone encoding the human $\mu$ opioid receptor was isolated. The deduced protein sequence of this receptor is very similar to that of its homolog from the rat brain (Chen et al., 1993a). Although the N-terminus of the human $\mu$ opioid receptor contains two additional amino acids not found in the rat homolog, the protein sequences are so similar that only two conservative amino acid substitutions occur in the region between TM1 and TM7, the core region of G-protein-coupled receptors that are involved in ligand binding and signal transduction. Such structural conservation between the human and rat $\mu$ opioid receptors would imply a functional conservation. Pharmacologically, they display very similar binding profiles for $\mu$-selective and nonselective ligands. Binding studies using brain homogenate have shown that opioid narcotics that have high liability of abuse, such as morphine and fentanyl, all bind to the $\mu$ opioid receptor rather selectively (Pasternak, 1993). Using the murine cDNA clones to express the $\mu, \delta$, and 

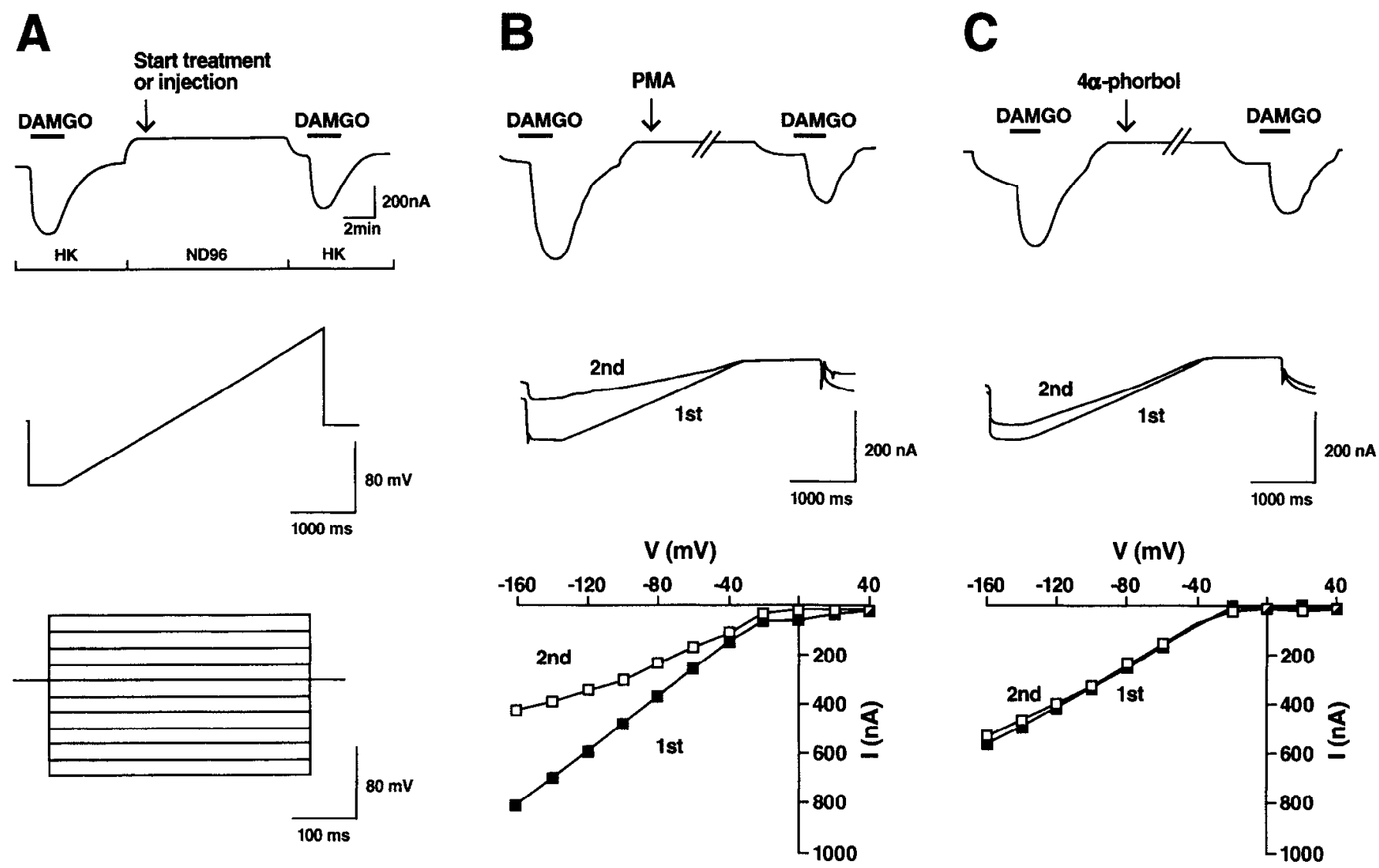

Figure 5. Desensitization of the $\mu$ opioid receptor $-\mathrm{K}^{+}$channel coupling and the effect of PKC. Membrane currents were recorded in oocytes injected with both the human $\mu$ opioid receptor and the $\mathrm{K}^{+}$channel mRNAs. A: Top, A schematic diagram of the experimental protocol. The oocyte was voltage clamped at $-80 \mathrm{mV}$ and superfused with $500 \mathrm{nM}$ DAMGO in HK solution to elicit the $\mathrm{K}^{+}$current. After the first DAMGO stimulation, the superfusate was switched to ND96 containing $1.8 \mathrm{mM} \mathrm{CaCl}_{2}$ and the oocyte either received no treatment or was subjected to drug treatment or enzyme injection. The superfusate was then switched back to HK solution to record the second DAMGO-induced membrane current. The recorded membrane current trace is shown. Please note that changes in the basal current level upon solution change between HK and ND96 reflects a larger $\mathrm{K}^{+}$current in HK due to elevated $\mathrm{K}^{+}$concentration. A: Middle, The ramped voltage command used to record currents before and during DAMGO stimulation. From a holding potential of $80 \mathrm{mV}$, the membrane voltage was stepped to $-160 \mathrm{mV}$, and ramped to $+40 \mathrm{mV}$ before stepping back to the holding potential. Net currents were derived by subtracting the currents before DAMGO application from those during DAMGO application. $A, B o t t o m$, The step voltage commands used to record currents before and during DAMGO application. The step command ranged from - $160 \mathrm{mV}$ to $+40 \mathrm{mV}$, with $20 \mathrm{mV}$ increments. Net currents were derived by subtracting the currents before DAMGO application from those during DAMGO application. $B$, Membrane currents elicited by DAMGO application before and after treatment with $100 \mathrm{nM}$ PMA for 10-15 min. $B$ : Top, Current recorded at a holding potential of $-80 \mathrm{mV}$. B: Middle and bottom, Net currents from the first and second DAMGO applications are obtained from either ramped (middle) or stepped (bottom) voltage commands. $C$, Membrane currents recorded during DAMGO application before and after treatment with $100 \mathrm{nM} 4 \alpha$-phorbol for 10-15 min. C: Top/middle/bottom, Membrane currents are recorded and displayed as in $B$.

K opioid receptors, these opioid narcotics showed highly selective binding at the $\mu$ receptor (Raynor et al., 1994). With the human $\mu$ opioid receptor, we now also observed nM affinities of the receptor for these compounds (Table 1). Also, $\mathrm{IC}_{50}$ values for DAMGO, naloxone, morphine, and diprenorphine using huInlan brain preparations (Pilapil et al., 1987; Pfeiffer et al., 1982) are in excellent agreement with those reported here. Since these ligands possess both powerful analgesic effects and abuse potential, the $\mu$ opioid receptor may, indeed, be the physiological mediator of the nociceptive and addictive properties of these narcotics. During the preparation of this manuscript, another human $\mu$ opioid receptor, designated $h \mu O R 1$, was reported (Wang et al., 1994) that differs from the receptor we cloned by one amino acid in the $\mathrm{N}$-terminal region. The binding profiles are almost identical.

A major effect of the $\mu$ opioid receptor activity in brain is the decrease of neuronal membrane excitability. One of the mechanisms for this effect is an increase in $\mathrm{K}^{+}$conductance, accom- plished by the opening of an inward rectifier, resulting in outward $\mathrm{K}^{+}$currents and hyperpolarization of the cell membrane (North, 1986, 1993; Chavkin, 1988). With the cloning of an inwardly rectifying $\mathrm{K}^{+}$channel that can be activated by a number of neurotransmitter receptors (Dascal et al., 1993; Kubo et al., 1993), it became possible to examine whether the $\mu$ opioid receptor could also activate this channel. We have shown that the $\mu$ opioid receptor from both rat (Chen and $\mathrm{Yu}, 1994)$ and human (Fig. 4) can activate this channel, causing an increase in $\mathrm{K}^{+}$conductance. The receptor-channel coupling is clearly mediated through heterotrimeric G-proteins, since a nonhydrolyzable GTP analog, guanosine 5 - $O$-(thiotriphosphate) (GTP- $\gamma S$ ), can enhance the $\mu$ receptor-activated $\mathrm{K}^{+}$current while pertussis toxin treatment decreases it (Chen and Yu, 1994). Thus, our data suggest that the $\mu$ receptor-channel coupling may be the basis for the $\mu$ receptor-induced increase in $\mathrm{K}^{+}$conductance.

Receptor-mediated signaling processes often display desensitization, operationally defined as a decrease in the cellular re- 

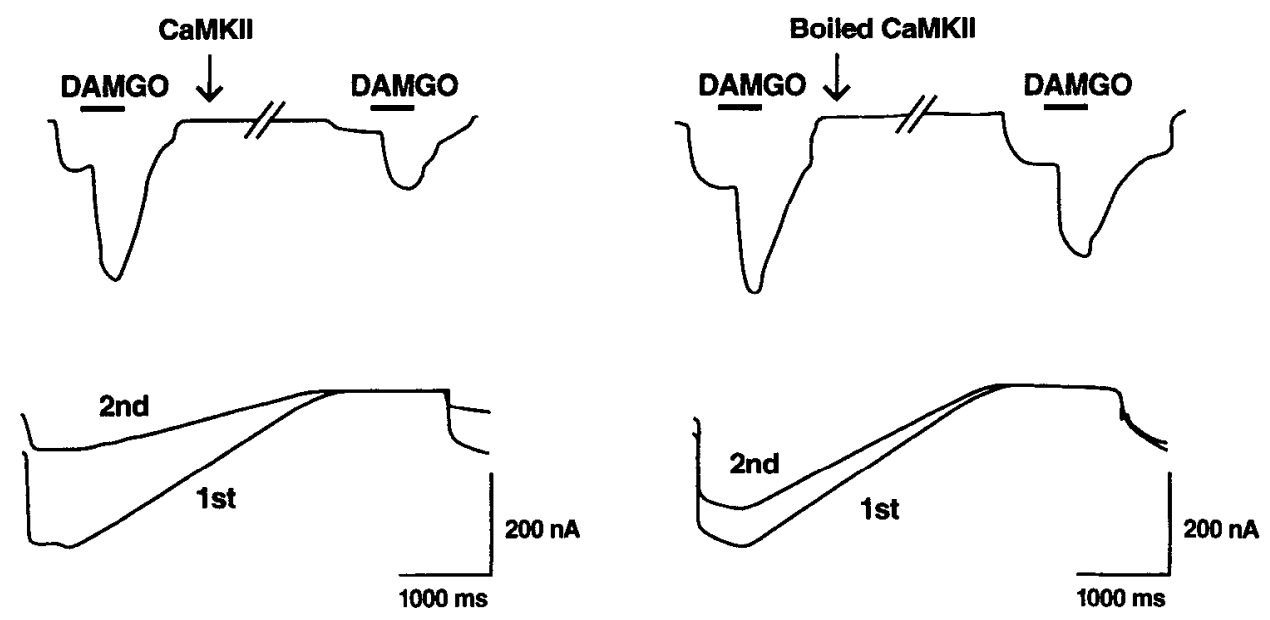

Figure 6. Effect of CaM kinase II on the coupling between the human $\mu$ opioid receptor and $\mathrm{K}^{+}$channel. Membrane currents were recorded in oocytes injected with both the human $\mu$ opioid receptor and the $\mathrm{K}^{+}$channel mRNAs. Experimental protocol and voltage commands are as described in Figure 5. A: Top/middle/bottom, Membrane currents recorded during DAM-

$\mathrm{V}(\mathrm{mV})$

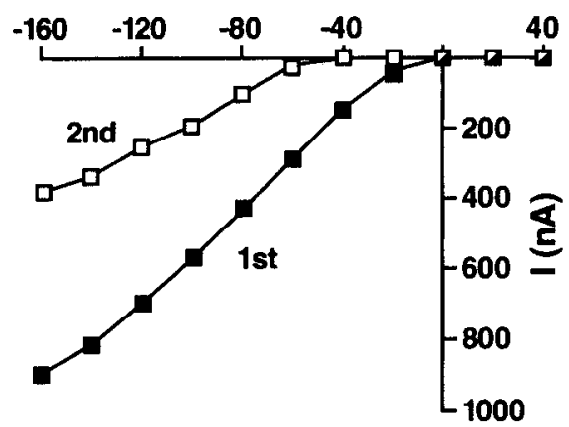
GO application before and after injection of activated CaM kinase II. A: Top, Current recorded at a holding potential of $-80 \mathrm{mV}$. A: Middle and bottom, Net currents from the first and second DAMGO applications are obtained from ramped (middle) or stepped (bottom) voltage commands. B: Top/middlelbottom, Membrane currents recorded during DAMGO application before and after injection of boiled CaM kinase II. Membrane currents are recorded and displayed as in the top, middle and bottom panels of $A$.

sponse to further agonist stimulation upon continuous or repeated exposure to agonist (Benovic et al., 1988). This may serve as a physiological mechanisin to prevent overstimulation of the neuron. The $\mu$ opioid receptor is the physiological target of morphine and fentanyl, analgesics used in the clinical management of pain. Prolonged use of morphine and related opioids can lead to the development of tolerance, necessitating dosage increases to achieve the same degree of its initial physiological effect. At the cellular level, tolerance manifests itself as a desensitized responsiveness to repeated opioid applications, and it has been hypothesized that several intermediates within the signal transduction pathway may serve as targets for this mechanism (Nestler et al., 1993). In the neurons of the rat locus coeruleus, desensitization was observed as a reduction in membrane hyperpolarization upon continued application of $\mathrm{Met}^{5}$-enkephalin. A decrease in $\mathrm{K}^{+}$conductance was shown to be responsible for the observed effect (Harris and Williams, 1991). In oocytes expressing the human $\mu$ opioid receptor and the inwardly rectifying $\mathrm{K}^{+}$channel, we used a protocol to evaluate desensitization by measuring the $\mathrm{K}^{+}$currents evoked by sequential acti-

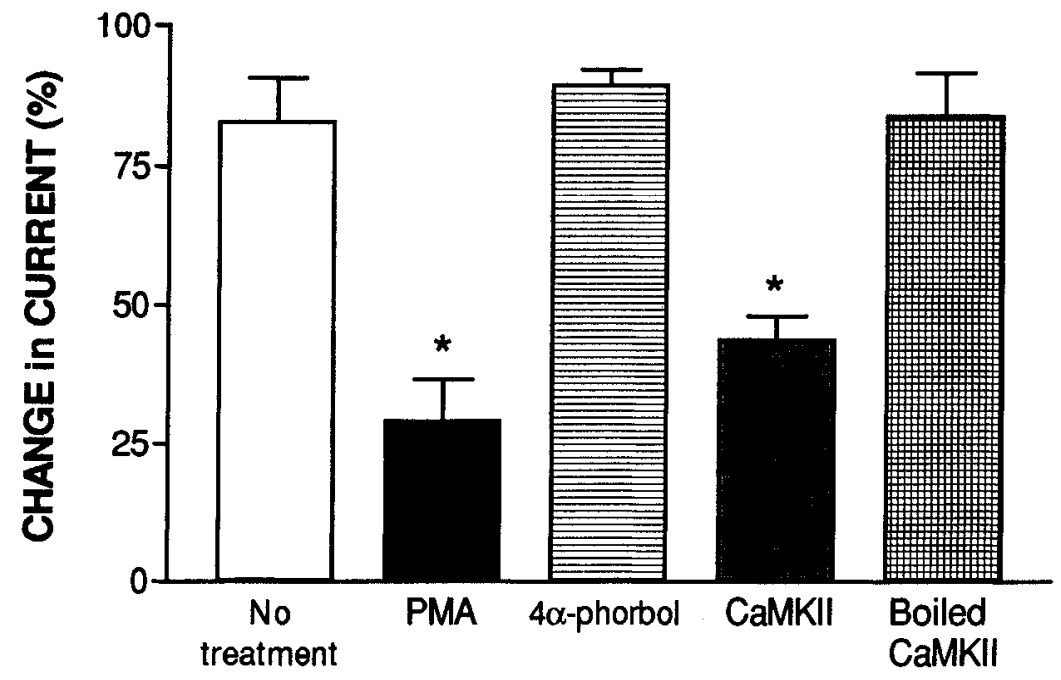

Figure 7. Desensitization of the human $\mu$ opioid receptor-induced $\mathrm{K}^{+}$current and modulation by $\mathrm{PKC}$ and $\mathrm{CaM}$ kinase II. Oocytes were injected with both the human $\mu$ opioid receptor and the inwardly rectifying $\mathrm{K}^{+}$channel mRNAs. Membranc currents were recorded at a holding potential of -80 $\mathrm{mV}$ during DAMGO application and recording of peak currents. Data are expressed as the percentage of the peak current induced by the second DAMGO stimulation over that of the first stimulation and are presented as mean \pm SEM. Treatment is labeled on the bottom of each data group. Analysis of variance and post hoc test results: *Indicates $p<0.05$ as compared to untreated group. 
Figure 8. Diagram depicting a model for crosstalk between different receptor-coupled signaling pathways. The model is based on both the results from this study and the evidence reported in the literature. The human $\mu$ opioid receptor and another type of surface receptor are depicted in the cell membrane as $\mu$ and $R$, respectively. Open circles represent receptor ligands. Potassium channel is shown with ionic efflux. Abbreviations for intracellular proteins: $G$, guanine nucleotide binding protein; $P K C$, protein kinase $C$; $C a$ $M K I I$, multifunctional $\mathrm{Ca}^{2+} /$ calmodulin-dependent protein kinase; $P D E$, phosphodiesterase involved in $\mathrm{PIP}_{2}$ hydrolysis. Abbreviations for intracellular molecules: $D A G$, diacylglycerol; $P I P_{2}$, phosphatidylinositol 4,5-bisphosphate; $I P_{3}$, inositol 1,4,5-trisphosphate. $A r$ rows pointing from second-messenger molecules to proteins indicate a stimulatory influence. Arrows with (-) indicate an inhibitory effect on interactions. Upward arrow adjacent to $\mathrm{Ca}^{++}$ indicates an increase in intracellular calcium.

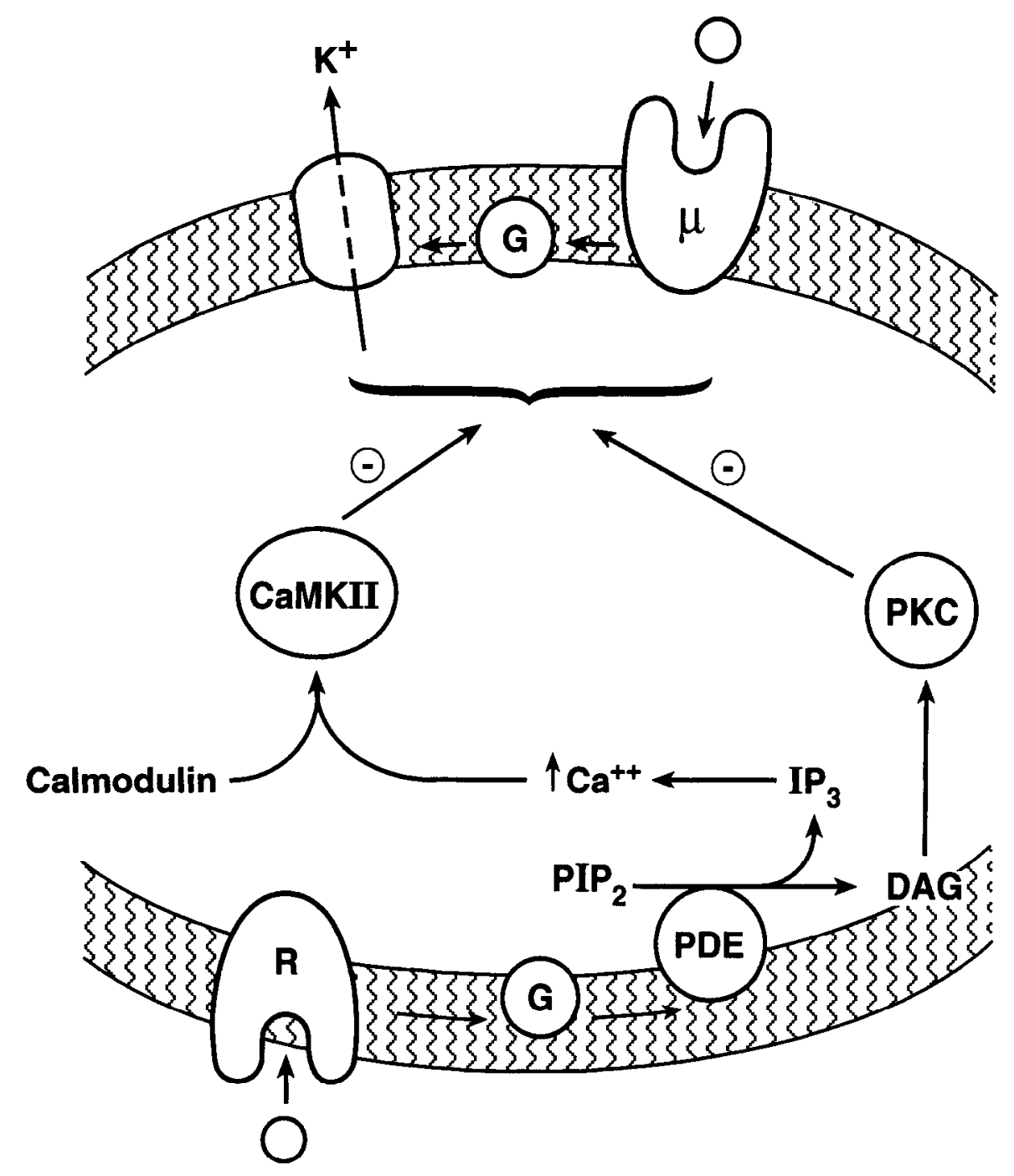

vation of the receptor with a $\mu$-selective agonist (Fig. $5 A$ ). Comparison of the maximum $\mathrm{K}^{+}$currents, thus, indicates the extent of desensitization between the first stimulus and second stimulus caused by activation of the receptor. Using this paradigm, desensitization occurred consistently, as observed in a reduction of the $\mathrm{K}^{+}$current to $\sim 80 \%$ of the initial response evoked by receptor activation (Fig. 7). Thus, desensitization of receptor-channel coupling appears to be a normal process when studied in oocytes, suggesting that such a phenomenon may exist as an adaptive process in neurons to modulate the responsiveness of the $\mu$ receptor-mediated increase in $\mathrm{K}^{+}$conductance.

Desensitization of receptor-channel coupling may involve several mechanisms at the cellular level. For acute desensitization such as that studied here with a time-scale of less than $30 \mathrm{~min}$, new protein synthesis or receptor turnover are unlikely to account for the majority of the observed effects. Covalent modification through kinase-mediated phosphorylation, on the other hand, appears to play an essential role. We demonstrated that both PKC and CaM kinase II potentiate desensitization (Figs. 5, 6). Activation of PKC by the phorbol ester PMA and injection of the activated type II CaM kinase both resulted in potentiation of desensitization (Fig. 7). In contrast, treatment with the inactive $4 \alpha$-phorbol ester or injection of boiled CaM kinase II did not potentiate desensitization beyond that observed in oocytes that had been untreated (Fig. 7), suggesting that the effect of potentiation is specific to the active form of these kinases. Our observations in Xenopus oocytes are consistent with the reports that in rat locus coeruleus neurons containing $\mu$ opioid receptors, treatment with staurosporine, a nonselective kinase inhibitor that can inhibit both PKC (Tamaoki, 1991) and CaM kinase II (Yanagihara et al., 1991), reduced desensitization of $\mu$ receptor-mediated hyperpolarization (Harris and Williams, 1991). Processes that elevate the activity of these cellular kinases, therefore, may play an important role in regulating the extent of the $\mu$ receptor$\mathrm{K}^{+}$channel coupling.

Both PKC and CaM kinase II are cellular effectors of a G-protein-activated phosphodiesterase, phospholipase $\mathrm{C}$ (PLC). The activation of PLC causes the production of $D \wedge G$ and $\mathrm{IP}_{3}$, two intracellular second-messenger molecules that represent a bifurcation in this signal transduction pathway (Berridge, 1987). Whereas DAG activates $\mathrm{PKC}, \mathrm{IP}_{3}$ triggers $\mathrm{Ca}^{2+}$ release from intracellular stores. Since CaM kinase II is activated by physiological elevations in cytosolic $\mathrm{Ca}^{2+}$ levels (MacNicol and Schulman, 1992; Schulman and Hanson, 1993), stimulation of receptors linked to PLC may cause activation of both PKC and CaM kinase. Other neurotransmitter receptors that belong to the family of G-protein-coupled receptors influence the steady-state levels of cAMP by either stimulating or inhibiting the activity 
of adenylyl cyclase, as is the case for the $\beta$-adrenergic and opioid receptors, respectively (Benovic et al., 1988; Childers, 1993). The widespread distribution of many G-protein-coupled receptors suggests that some may be found within similar structures of the brain. In fact, in situ hybridization has shown that messages encoding receptors that use either similar (Lester et al., 1993) or different (Weiner et al., 1990) signaling pathways do coexist within the same cell. Thus, crosstalk between different receptor-coupled signaling pathways may serve as a modulatory mechanism to fine tune the function of a neuron. Our results provide an example of such crosstalk, demonstrating the modulatory effect on $\mu$ opioid receptor- $\mathrm{K}^{+}$channel coupling by CaM kinase II and PKC, both of which are effectors of the PLC signaling pathway. The diagram in Figure 8 depicts a model of this crosstalk. In this model, the effect of both CaM kinase II and PKC on $\mu$ opioid receptor- $\mathrm{K}^{+}$channel coupling is marked with minus signs, highlighting the fact that these kinases potentiate the desensitization of the $\mu$ opioid receptor-mediated $\mathrm{K}^{+}$ current. It should be noted that our results only demonstrate the modulatory role of these kinases. The pathway from another type of membrane receptor through PLC to activate the kinases is based on reports in the literature and has not been shown in the oocyte expression system that we used. It should also be noted that it is not known which protein is the target of these kinases, whether the target be the $\mu$ opioid receptor, the G-protein, the $\mathrm{K}^{+}$channel, or some other intermediary factors. Thus, the diagram in Figure 8 only indicates the possibility that signal transduction mechanisms may affect one another, when the receptors to which they couple are present on the same neuron.

We have attempted to investigate the role of CaM kinase II and $\mathrm{PKC}$ in the mechanisms involved in acute desensitization. The schematic diagram in Figure 8 depicts the individual effects of these kinases on opioid receptor-mediated $\mathrm{K}^{+}$channel activity. Our data demonstrate that an intricate network of modulation among receptors, G-protein effectors, and protein kinases can function in oocytes with exogenously expressed receptors and ion channels as well as endogenous components, providing a possible mechanism of functional modulation that may occur in neurons to regulate opioid tolerance. With the cloning of the human $\mu$ opioid receptor, future efforts will focus on identifying other key elements involved in this modulatory network. Results from such studies will further our understanding of the molecular mechanisms that underlie the regulation of receptor-mediated neuronal activity, with particular focus on the cellular basis of the initial stages in the development of opioid tolerance.

\section{References}

Benovic JL, Bouvier M, Caron MG, Lefkowitz RJ (1988) Regulation of adenylyl cyclase-coupled $\boldsymbol{\beta}$-adrenergic receptors. Annu Rev Cell Biol 4:405-428.

Berridge MJ (1987) Inositol trisphosphate and diacylglycerol: two interacting second messengers. Annu Rev Biochem 56:159-193.

Blumberg PM, Jaken S, Konig B, Sharkey NA, Leach KL, Jeng AY, Yeh $E$ (1984) Mechanism of action of the phorbol ester tumor promoters: specific receptors for lipophilic ligands. Biochem Pharmacol 33:933-940.

Bradford MM (1976) A rapid and sensitive method for the quantitation of microgram quantities of protein utilizing the principle of proteindye binding. Anal Biochem 72:248-254.

Chavkin C (1988) Electrophysiology of opiates and opioid peptides. In: The opiate receptors (Pasternak GW, ed), pp 273-303. Clifton, NJ: Humana.

Cheng Y, Prusoff W (1973) Relationship between the inhibition constant $\left(K_{i}\right)$ and the concentration of inhibitor which causes 50 percent inhibition $\left(\mathrm{IC}_{50}\right)$ of an enzymatic reaction. Biochem Pharmacol 22: 3099-3108.

Chen Y, Yu L (1994) Differential regulation by cAMP-dependent protein kinase and protein kinase $C$ of the $\mu$ opioid receptor coupling to a $\mathrm{G}$ protein-activated $\mathrm{K}^{+}$channel. J Biol Chem 269:7839-7842.

Chen Y, Mestek A, Liu J, Hurley JA, Yu L (1993a) Molecular cloning and functional expression of a $\mu$-opioid receptor from rat brain. Mol Pharmacol 44:8-12.

Chen Y, Mestek A, Liu J, Yu L (1993b) Molecular cloning of a rat $\kappa$ opioid receptor reveals sequence similarities to the $\mu$ and $\delta$ opioid receptors. Biochem J 295:625-628.

Childers S (1993) Opioid receptor-coupled second messenger systems. In: Handbook of experimental pharmacology: opioids I, Vol 104 (Herz A, ed), pp 189-216. Berlin: Springer.

Collin E, Cesselin F (1991) Neurobiological mechanisms of opioid tolerance and dependence. Clin Neuropharmacol 14:465-488.

Collins S, Lohse MJ, O'Dowd B, Caron MG, Lefkowitz RJ (1991) Structure and regulation of $G$ protein-coupled receptors: the $\beta_{2}$-adrenergic receptor as a model. Vitam Horm 46:1-39.

Corbett A, Paterson S, Kosterlitz H (1993) Selectivity of ligands for opioid receptors. In: Handbook of experimental pharmacology: opioids I, Vol 104 (Herz A, ed), pp 645-679. Berlin: Springer.

Dascal N, Lim NF, Schreibmayer W, Wang W, Davidson N, Lester HA (1993) Expression of an atrial G-protein-activated potassium channel in Xenopus oocytes. Proc Natl Acad Sci USA 90:6596-6600.

Delfs J, Kong H, Mestek A, Chen Y, Yu L, Reisine T, Chesselet MF (1994) Expression of mu opioid receptor mRNA in rat brain. J Comp Neurol 345:46-68.

Devereux J, Haeberli P, Smithies O (1984) A comprehensive set of sequence analysis programs for the VAX. Nucleic Acids Res 12:387395.

Di Chiara G, North RA (1992) Neurobiology of opiate abuse. Trends Pharmacol Sci 13:185-193.

Dixon RA, Sigal IS, Strader CD (1988) Structure-function analysis of the $\beta$-adrenergic receptor. Cold Spring Harbor Symp Quant Biol 53: 487-497.

Doerner D, Pitler TA, Alger BE (1988) Protein kinase C activators block specific calcium and potassium current components in isolated hippocampal neurons. J Neurosci 8:4069-4078.

Dohlman HG, Thorner J, Caron MG, Lefkowitz RJ (1991) Model systems for the study of seven-transmembrane-segment receptors. Annu Rev Biochem 60:653-688.

Evans CJ, Keith DEJ, Morrison H, Magendzo K, Edwards RH (1992) Cloning of a delta opioid receptor by functional expression. Science 258:1952-1955.

Fukuda K, Kato S, Mori K, Nishi M, Takeshima H (1993) Primary structures and expression from cDNAs of rat opioid receptor $\delta$ - and $\mu$-subtypes. FEBS Lett 327:311-314.

Guitart X, Nestler EJ (1993) Second messenger and protein phosphorylation mechanisms underlying opiate addiction: studies in the rat locus coeruleus. Neurochem Res 18:5-13.

Gurdon JB, Wickens MP (1983) The use of Xenopus oocytes for the expression of cloned genes. Methods Enzymol 101:370-386.

Harris GC, Williams JT (1991) Transient homologous $\mu$-opioid receptor desensitization in rat locus coeruleus neurons. J Neurosci 11: 2574-2581.

Johnson SM, Fleming WW (1989) Mechanisms of cellular adaptive sensitivity changes: applications to opioid tolerance and dependence. Pharmacol Rev 41:435-488.

Kieffer BL, Befort K, Gaveriaux-Ruff C, Hirth CG (1992) The $\delta$-opioid receptor: isolation of a cDNA by expression cloning and pharmacological characterization. Proc Natl Acad Sci USA 89:1204812052.

Kubo Y, Reuveny E, Slesinger PA, Jan YN, Jan LY (1993) Primary structure and functional expression of a rat G-protein-coupled muscarinic potassium channel. Nalure 364:802-806.

Lester J, Fink S, Aronin N, DiFiglia M (1993) Colocalization of $D_{1}$ and $\mathrm{D}_{2}$ dopamine receptor mRNAs in striatal neurons. Brain Res 621: 106-110.

Li S, Zhu J, Chen C, Chen YW, Deriel JK, Ashby B, Liu-Chen LY (1993) Molecular cloning and expression of a rat $\kappa$ opioid receptor. Biochem J 295:629-633.

Loh HH, Tao PL, Smith AP (1988) Role of receptor regulation in opioid tolerance mechanisms. Synapse 2:457-462.

Louie AK, Bass ES, Zhan J, Law PY, Loh HH (1990) Attenuation of 
opioid receptor activity by phorbol esters in neuroblastoma $\times$ glioma NG108-15 hybrid cells. J Pharmacol Exp Ther 253:401-407.

MacNicol M, Schulman H (1992) Multiple $\mathrm{Ca}^{2+}$ signaling pathways converge on CaM kinase in PC12 cells. FEBS Lett 304:237-240.

Mansour A, Khachaturian H, Lewis ME, Akil H, Watson SJ (1987) Autoradiographic differentiation of mu, delta, and kappa opioid receptors in the rat forebrain and midbrain. J Neurosci 7:2445-2464.

Mansour A, Khachaturian H, Lewis ME, Akil H, Watson SJ (1988) Anatomy of CNS opioid receptors. Trends Neurosci 11:308-314.

Meng F, Xie GX, Thompson RC, Mansour A, Goldstein A, Watson SJ, Akil H (1993) Cloning and pharmacological characterization of a rat $\kappa$ opioid receptor. Proc Natl Acad Sci USA 90:9954-9958.

Minami M, Toya T, Katao Y, Maekawa K, Nakamura S, Onogi T, Kaneko S, Satoh M (1993) Cloning and expression of a cDNA for the rat K-opioid receptor. FEBS Lett 329:291-295.

Munson PJ (1983) LIGAND: a computerized analysis of ligand binding data. Methods Enzymol 92:543-576.

Nestler EJ, Hope BT, Widnell KL (1993) Drug addiction: a model for the molecular basis of neural plasticity. Neuron 11:995-1006.

Nock B, Rajpara A, O'Connor LH, Cicero TJ (1988) Autoradiography of $\left[{ }^{3} \mathrm{H}\right] \mathrm{U}-69593$ binding sites in rat brain: evidence for kappa opioid receptor subtypes. Eur J Pharmacol 154:27-34.

North RA (1986) Opioid receptor types and membrane ion channels. Trends Ncurosci 9:114-117.

North R (1993) Opioid actions on membrane ion channels. In: Handbook of experimental pharmacology: opioids I, Vol 104 (Herz A, ed), pp 773-797. Berlin: Springer.

North RA, Williams JT, Surprenant A, Christie MJ (1987) $\mu$ and $\delta$ receptors belong to a family of receptors that are coupled to potassium channels. Proc Natl Acad Sci USA 84:5487-5491.

Pasternak GW (1988) The opiate receptors. Totowa, NJ: Humana

Pasternak GW (1993) Pharmacological mechanisms of opioid analgesics. Clin Neuropharmacol 16:1-18.

Pfeiffer A, Pasi A, Mehraein P, Herz A (1982) Opiate receptor binding sites in human brain. Brain Res 248:87-96.

Pilapil C, Welner S, Magnan J, Gauthier S, Quirion R (1987) Autoradiographic distribution of multiple classes of opioid receptor binding sites in human forebrain. Brain Res Bull 19:611-615.

Porreca F, Mosberg HI, Hurst R, Hruby VJ, Burks TF (1984) Roles of mu, delta and kappa opioid receptors in spinal and supraspinal mediation of gastrointestinal transit effects and hot-plate analgesia in the mouse. J Pharmacol Exp Ther 230:341-348.

Raynor K, Kong H, Yasuda K, Chen Y, Yu L, Bell GI, Reisine T (1994) Pharmacological characterization of the clones $\kappa, \delta$ and $\mu$ opioid receptors. Mol Pharmacol 45:330-334.

Schulman II (1984) Phosphorylation of microtubule-associated pro- teins by a $\mathrm{Ca}^{2+} /$ calmodulin-dependent protein kinase. J Cell Biol 99: $11-19$.

Schulman H, Hanson PI (1993) Multifunctional $\mathrm{Ca}^{2+} /$ calmodulin-dependent protein kinase. Neurochem Res 18:65-77.

Tamaoki T (1991) Use and specificity of staurosporine, UCN-01, and calphostin $\mathrm{C}$ as protein kinase inhibitors. Methods Enzymol 201:340347

Thompson RC, Mansour A, Akil H, Watson SJ (1993) Cloning and pharmacological characterization of a rat $\mu$ opioid receptor. Neuron 11:903-913.

Unterwald EM, Knapp C, Zukin RS (1991) Neuroanatomical localization of kappa 1 and kappa 2 opioid receptors in rat and guinea pig brain. Brain Res 562:57-65.

Waldmann R, Hanson PI, Schulman H (1990) Multifunctional $\mathrm{Ca}^{2+} /$ calmodulin-dependent protein kinase made $\mathrm{Ca}^{2+}$-independent for functional studies. Biochemistry 29:1679-1684.

Wang JB, Imai Y, Eppler CM, Gregor P, Spivak CE, Uhl GR (1993) $\mu$ Opiate receptor: cDNA cloning and expression. Proc Natl Acad Sci USA 90:10230-10234

Wang JB, Johnson PS, Persico AM, Hawkins AL, Griffin CA, Uhl GR (1994) Human $\mu$ opiate receptor: cDNA and genomic clones, pharmacologic characterization and chromosomal assignment. FEBS Let $338: 217-222$

Weiner DM, Levey AI, Brann MR (1990) Expression of muscarinic acetylcholine and dopamine receptor mRNAs in rat basal ganglia. Proc Natl Acad Sci USA 87:7050-7054.

Williams JT, North RA, Tokimasa T (1988) Inward rectification of resting and opiate-activated potassium currents in rat locus coeruleus neurons. J Neurosci 8:4299-4306.

Wimpey TL, Chavkin C (1991) Opioids activate both an inward rectifier and a novel voltage-gated potassium conductance in the hippocampal formation. Neuron 6:281-289.

Wood PL (1988) The significance of multiple CNS opioid receptor types: a review of critical considerations relating to technical details and anatomy in the study of central opioid actions. Peptides 9:49 55.

Wood PL, Iyengar S (1988) Central actions of opiates and opioid peptides: in vivo evidence for opioid receptor multiplicity. In: The opiate receptors (Pasternak GW, ed), pp 307-356. Clifton, NI: Humana.

Yaksh TL (1981) Spinal opiate analgesia: characteristics and principles of action. Pain 11:293-346.

Yanagihara N, Tachikawa E, Izumi F, Yasugawa S, Yamamoto H, Miyamoto E (1991) Staurosporine: an effective inhibitor for $\mathrm{Ca}^{2+} /$ calmodulin-dependent protein kinase II. J Neurochem 56:294 298

Yasuda K, Raynor K, Kong H, Breder CD, Takeda J, Reisine T, Bell GI (1993) Cloning and functional comparison of $\kappa$ and $\delta$ opioid receptors from mouse brain. Proc Natl Acad Sci USA 90:6736-6740. 